\title{
CD65 Negative
}

National Cancer Institute

\section{Source}

National Cancer Institute. CD65 Negative. NCI Thesaurus. Code C162072.

An indication that CD65 antigen expression has not been detected in a sample. 